\title{
Grape Seed Proanthocyanidin Alleviates Oxidative Stress and Apoptosis Involved in Liver of Hyperthyroid Mice
}

\author{
Maha Abdulrahman Aldubayan ${ }^{1 *}$ \\ ${ }^{1}$ Department of Pharmacology and Toxicology, Faculty of Pharmacy, Qassim University, Buraydah, \\ 51452, Saudi Arabia.
}

Author's contribution

The sole author designed, analysed, interpreted and prepared the manuscript.

Article Information

DOI: $10.9734 / A R R B / 2019 / v 33 i 630138$

Editor(s):

(1) Paola Angelini, Department of Applied Biology, University of Perugia, Perugia, Italy.

Reviewers:

(1) Gayatri C. Gawade, BVDTUMC, India.

(2) Senthil Kumar Raju, Swamy Vivekanandha College of Pharmacy, India.

(3) Sandeep Kumar Agarwal, Christian Medical College and Hospital, India. Complete Peer review History: http://www.sdiarticle4.com/review-history/53015

Original Research Article

Received 19 September 2019

Accepted 24 November 2019

Published 03 December 2019

\begin{abstract}
Objectives: Thyroid hormones control the basal metabolic pace of hepatocytes, and can make oxidative harm hepatic frameworks. The reason for this investigation was to investigate how hyperthyroidism-prompted liver danger, oxidative pressure and apoptosis changes could be alleviated with Grape seed proanthocyanidin extract (GSPE). This investigation assessed some biochemical, histological and immunohistochemical changes in post pubertal hyperthyroidism and its effect on liver capacity and structures. Notwithstanding the enhancing job of Grape seed proanthocyanidin remove (GSPE) supplementation was analyzed.

Materials and Methods: Fifty male Swiss albino mice were randomly divided into 5 groups (G1, Control; G2, GSPE; G3, Eltroxin-induced hyperthyroid mice; G4, Post treated hyperthyroid with GSPE; G5, Self-treated hyperthyroid mice).

Results: Our results revealed that, a significant increase in serum T3, T4, ALT, AST, ALP, liver MDA, P53 levels, injury and P53 expression in hyperthyroid mice when compared to control and GSPE. In contrast; serum albumin, liver catalase, GSH, SOD and Bcl2 were decrease in hyperthyroid mice. Treatment of hyperthyroid mice with GSPE advantages in improving the adverse effect of hyperthyroidism and moreover the histopathological and P53 expression
\end{abstract}


result approves this finding.

Conclusions: GSPE can be used in hyperthyroidism treatment to help propylthiouracil or carbimazole or methimazole therapy.

Keywords: Hyperthyroidism; grape seed proanthocyanidin; hepatic dysfunction; oxidative stress; liver injury and PCNA.

\section{INTRODUCTION}

Hyperthyroidism is one of the most open endocrine issues found in medicinal practice, elevated levels in serum liver and kidney chemicals are regular going with hazard elements of hyperthyroidism [1]. Hyperthyroidism is portrayed by expanded discharge of thyroid hormones tiroiodothyronin as well as thyroxin $[2,3]$. Thyroxine and tri-iodothyronine are thyroid hormones that basic for typical organ improvement and metabolic capacities [4-10]. Thyroid hormones modify the basal metabolic pace of hepatocytes and along these lines control hepatic capacity $[11,12]$. The liver is biggest organ in the body and it assumes a significant job in our digestion where it is the principle site for lipid digestion, and the thyroid hormones have a basic impact in hepatic lipid homeostasis $[13,14]$. Hence it isn't astounding that expanded digestion in light of hyperthyroidism can make hepatic brokenness and oxidative harm hepatic frameworks [15]. Several plant extracts have significant antioxidant activity; one of this is a grape seeds that is rich sources for proanthocyanidins [16-19]. Proanthocyanidins are consists of many polyphenolic compounds and it have become of high importance because of their biological properties (anti-oxidant, anti-inflammatory and anti-carcinogenic) and their protective effects by reducing mitochondria damage and inhibiting cell apoptosis [20,21]. Grape seed proanthocyanidin extract (GSPE) is believed to protect against reactive oxygen species (ROS)-mediated myocardial ischemia/reperfusion injury and apoptosis [22,23]. GSPE have free radical searching properties are more noteworthy than well known cancer prevention agents, for example, nutrients $\mathrm{C}$ and $\mathrm{E}$, and it demonstrates a better capacity than secure cells against lipid peroxidation and DNA fracture [24]. Subsequently; the present investigation was intended to explain the conceivable enhancing impacts of GSPE in improving hepatic lethality, apoptosis, oxidative pressure, damage, and apoptosis adjustments against Eltroxin instigated hyperthyroidism in male mice.

\section{MATERIALS AND METHODS}

\subsection{Chemicals and Drug}

ELTROXIN (Thyroxine 100 mcg; 100 Tablet) was obtained from Mercury Pharma Group Limited, Capital House, London EC4N 7BL, UK.

Grape seed proanthocyanidin (GSPE; 200mg; Pharco Pharmaceuticals Co. Alexandria, Egypt) with 95.0-96.29\% Purity of Oligomeric Proanthocyanidins.

\subsection{Animals}

A total of 50 male Swiss albino mice (Mus musculus) 6-8 weeks old, weighing $25 \pm 2 \mathrm{~g}$, supplied from the animal house of the King Saud University, Riyadh, Saudi Arabia. Animals were provided standard mice feed and water ad libitum.

\subsection{Experimental Design and Mice Groups}

The mice were equally divided into 5 groups with ten rats each.

G1 : Control group in which mice did not received any treatment.

G2 : GSPE; mice received GSPE (50 $\mathrm{mg} / \mathrm{Kg} /$ day) only for three weeks orally by a stomach tube [17].

G3 : Hyperthyroid; mice received $100 \mu \mathrm{g} / \mathrm{Kg}$ Eltroxin in drinking water for 3 weeks to induce the hyperthyroid state [2].

G4 : Post treated hyperthyroid; mice received $100 \mu \mathrm{g} / \mathrm{Kg}$ Eltroxin in drinking water for 3 weeks and then treated with GSPE for another 3 weeks (from $4^{\text {th }}$ week to $6^{\text {th }}$ week).

G5 : Self-treated hyperthyroid; mice received $100 \mu \mathrm{g} / \mathrm{Kg}$ Eltroxin in drinking water for 3 weeks and then mice did not received any treatment for another 3 weeks (from $4^{\text {th }}$ week to $6^{\text {th }}$ week) according to Tousson et al. [13].

At the end of the experiment period, blood samples were individually collected from the eyes by retro-orbital puncture using blood 
capillary tubes in non-heparinized glass tubes under mild ether anesthesia. Blood samples were centrifuged to obtain serum used for detection of thyroid hormones and liver functions.

\subsection{Determination of Serum Thyroid Hormones}

Serum was used to determine the triiodothyronine $\left(T_{3}\right)$ according to Thakur et al. [25]; thyroxine $\left(\mathrm{T}_{4}\right)$ according to Ibrahim et al. [26] and thyrotropin (TSH) according to Ibrahim et al. [27].

\subsection{Determination of Serum Liver Enzymes}

Serum was analyzed to determine aspartate transaminase (AST) and alanine transaminase (ALT) activities using commercial kit (Humann, Germany) according to the method of ElMoghazy et al. [28]; serum albumin levels by using commercial kit (Diamond, Egypt) according to Doumas et al. [29]; serum alkaline phosphatase (ALP) activity in serum was detected by using commercial kit (Humann, Germany) according to Moss and Henderson [30].

\subsection{Preparation of Tissue Homogenates}

Liver from different groups were removed, weighed and stored at $-20^{\circ} \mathrm{C}$ then $10 \% \mathrm{~W} / \mathrm{V}$ homogenate was prepared by grand $0.3 \mathrm{~g}$ of tissue in $3 \mathrm{ml}$ of saline, liver homogenates were used to estimate the oxidative stress parameters.

\subsection{Enzymatic and Non-enzymatic Antioxidant Assays}

Determination of malondialdehyde (MDA) levels in homogenate was assayed according to Moustafa et al. [31], catalase (CAT) was detected after Saggu et al. [32], superoxide dismutase (SOD) activity was detected after Misra and Fridovich [33] and reduced glutathione (GSH) content was detected after Beutler et al. [34].

\subsection{Determination of P53 and Bcl2 Protein Levels}

P53 and Bcl2 protein levels were determine after the method of Tousson et al. [35].

\subsection{Histological Preparation}

The changes in the liver structure were prepared according to the method of Tousson [36].

\subsection{Detection of Apoptotic P53 Expressions}

P53 immunoreactivity were detected after the method to Tousson et al. [8,37].

\subsection{Statistical Analysis}

Information were communicated as mean qualities $\pm \mathrm{SE}$ and factual examination was performed utilizing one route ANOVA to survey huge contrasts among treatment groups. The measure for factual essentialness was set at $p<0.05$ for the biochemical information. Every single measurable investigation were performed utilizing SPSS factual form 21 programming bundle (SPSS $®$ Inc., USA).

\section{RESULTS}

\subsection{Induction of Hyperthyroid Mice}

Fig. $1 \mathrm{~A}-1 \mathrm{C}$ showed that; the serum $\mathrm{T}_{3}$ and $\mathrm{T}_{4}$ levels in hyperthyroid and self-recovered hyperthyroid mice were significantly higher as compared to control; In contrast; serum TSH levels in hyperthyroid and self-recovered hyperthyroid mice were significantly lower as compared to control (Fig. 1A). The treatment of hyperthyroid mice with GSPE revealed a significant decrease in $T_{3}$ and $T_{4}$ levels as compared with hyperthyroid mice (Fig. 1B \& 1C). Also; Treatment of hyperthyroid mice with GSPE revealed a significant increase in TSH levels as compared with hyperthyroid mice group.

\subsection{Changes in Liver Functions in Different Groups}

Table (1) showed that; a significance increase in serum ALT, AST and ALP levels in hyperthyroid mice and self-recovered hyperthyroid mice groups as compared with control and treated mice with GSPE. In contrast; significance decreases in serum albumin in hyperthyroid mice and self-recovered hyperthyroid mice as compared to control and treated mice with GSPE. On the other hand; treatment of hyperthyroid mice with GSPE revealed a significant decrease in ALT, AST and ALP levels as compared with hyperthyroid mice group. In addition to the treatment of hyperthyroid mice with GSPE revealed a significant increase in albumin levels as compared with hyperthyroid group (Table 1). 


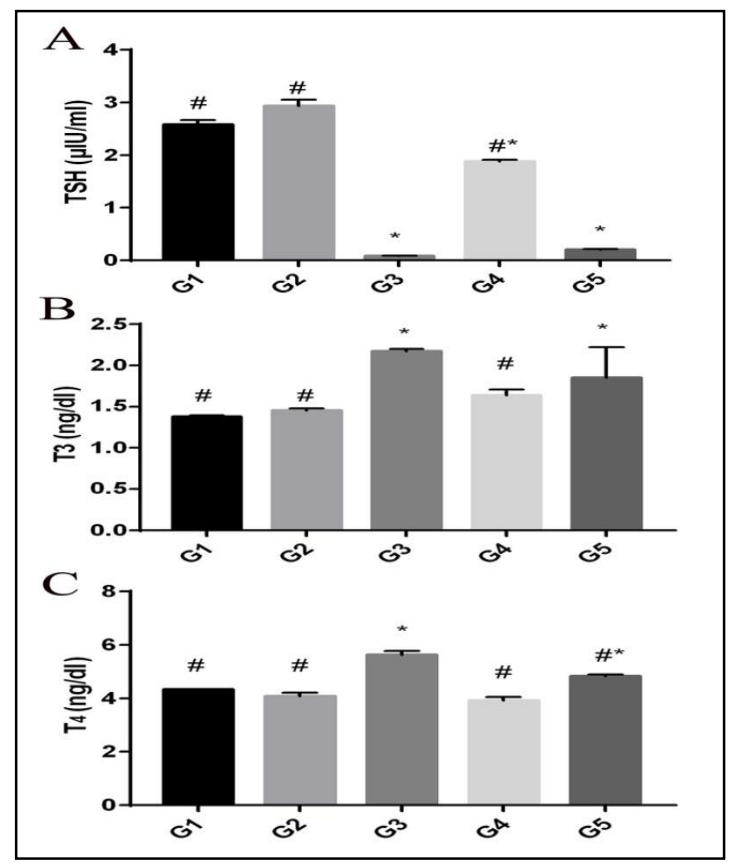

Fig. 1. Changes in thyrotropin (TSH; $\mu \mathrm{lU} / \mathrm{ml})$, thyroxine (T4; ng/dl) and triiodothyronine (T3; $\mathrm{ng} / \mathrm{dl}$ ) levels in different experimental groups; data are expressed as mean \pm standard error; G1, control; G2, GSPE; G3, hyperthyroid; G4, post-treated hyperthyroid with GSPE; G5, selftreated hyperthyroid; " significantly different from G3, *significantly different from G1

Table 1. Changes in liver functions (ALT, AST, ALP, and Alb) parameters

\begin{tabular}{|c|c|c|c|c|c|}
\hline & G1 & G2 & G3 & G4 & G5 \\
\hline $\operatorname{ALT}(\mathrm{U} / \mathrm{I})$ & $37.5^{\#} \pm 1.81$ & $31.1^{\#} \pm 2.15$ & $66.3^{*} \pm 4.58$ & $40.6^{\#_{\star}} \pm 3.19$ & $58.4^{*} \pm 4.43$ \\
\hline AST (U/I) & $136.2^{\#} \pm 8.56$ & $130.5^{\#} \pm 10.18$ & $171.0^{*} \pm 10.45$ & $134.52^{\#} \pm 11.22$ & $165.1^{*} \pm 10.88$ \\
\hline $\operatorname{ALP}(U / I)$ & $161.9^{\#} \pm 11.25$ & $147.4^{\#} \pm 8.69$ & $193.1^{*} \pm 10.33$ & $169.8^{\#_{\star}} \pm 11.49$ & $180.2^{*} \pm 12.05$ \\
\hline Alb (g/dl) & $4.55^{\#} \pm 0.216$ & $4.78^{\#} \pm 0.185$ & $3.35^{\star} \pm 0.164$ & $4.60^{\#} \pm 0.228$ & $3.40^{*} \pm 0.157$ \\
\hline
\end{tabular}

\subsection{Lipid Peroxidation and Reduced Glutathione Content}

Fig. $2 \mathrm{~A}$ shows a significant $(P<0.05)$ increase in the liver MDA levels in hyperthyroid and selftreated hyperthyroid mice as compared with control mice. Our data showed a significant $(P<0.05)$ decrease in GSH levels in liver of hyperthyroid and self-treated hyperthyroid mice as compared with control mice (Fig. 2B). On the other hand, hyperthyroid mice treated with GSPE showed significant depletion in liver MDA and alleviation in GSH levels as compared with hyperthyroid mice (Fig. 2A \& 2B).

\subsection{Antioxidant Enzyme Activities}

A significantly $(P<0.05)$ decreased in the activities of SOD and CAT was detected in liver homogenate of hyperthyroid and self-treated hyperthyroid mice (Fig. 2C \& 2D). Hyperthyroid mice treated with GSPE showed significant alleviation in the antioxidant enzyme activities as compared with hyperthyroid and self-treated hyperthyroid mice. Moreover, antioxidant enzyme activities were significant increase in mice treated with GSPE alone as compared to control (Fig. 2C \& 2D).

\subsection{Hyperthyroidism Induced Apoptosis in Mice Liver}

Fig. 3 show the concentration of $\mathrm{P} 53$ and $\mathrm{Bc} / 2$ levels in mice liver tissues. The levels of P53 were significant $(P<0.05)$ increase in hyperthyroid and self-treated hyperthyroid mice when compared with control (Fig. 3A \& 3B). While $\mathrm{Bcl} 2$ levels were significant $(P<0.05)$ 
depletion in hyperthyroid and self-treated hyperthyroid mice when compared with control. Treatment of hyperthyroid mice with GSPE improved this alternation of $\mathrm{P} 53$ and $\mathrm{Bcl} 2$ concentrations in liver tissues (Fig. 3).

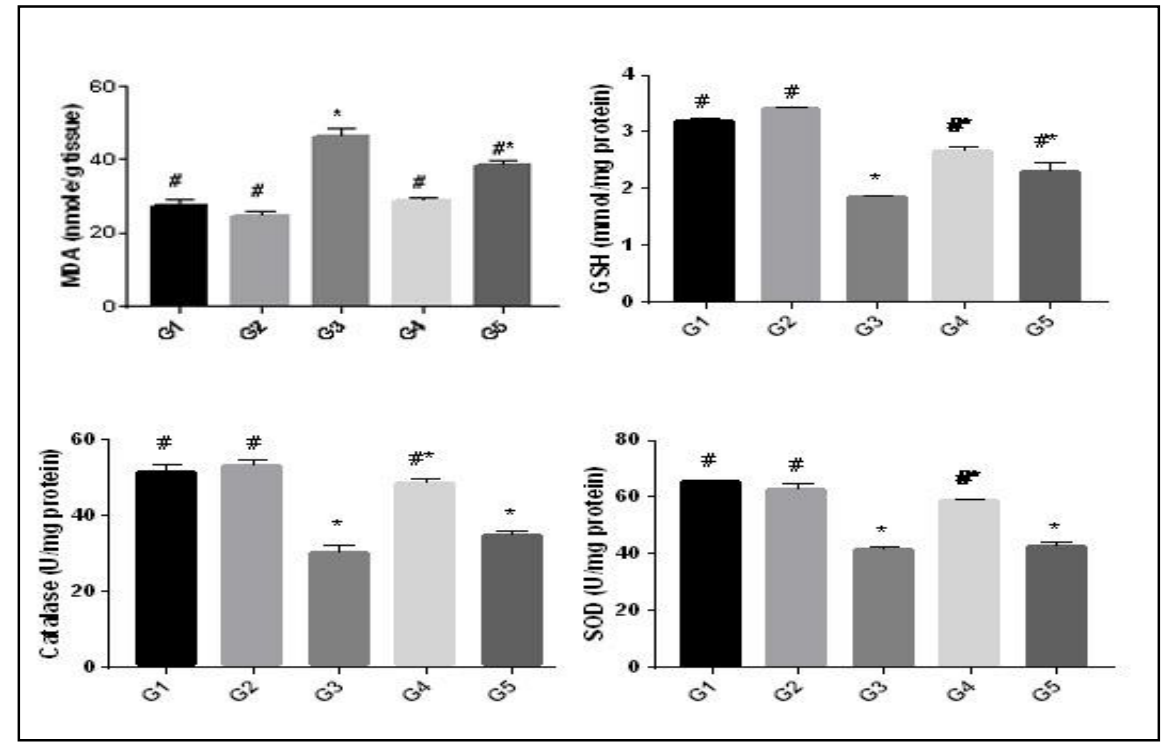

Fig. 2. Changes in MDA, GSH, and catalase and SOD levels in liver tissues in different experimental groups; data are expressed as mean \pm standard error; G1, control; G2, GSPE; G3, hyperthyroid; G4, post-treated hyperthyroid with GSPE; G5, self-treated hyperthyroid \# significantly different from $\mathrm{G} 3$, *significantly different from $\mathbf{G} 1$

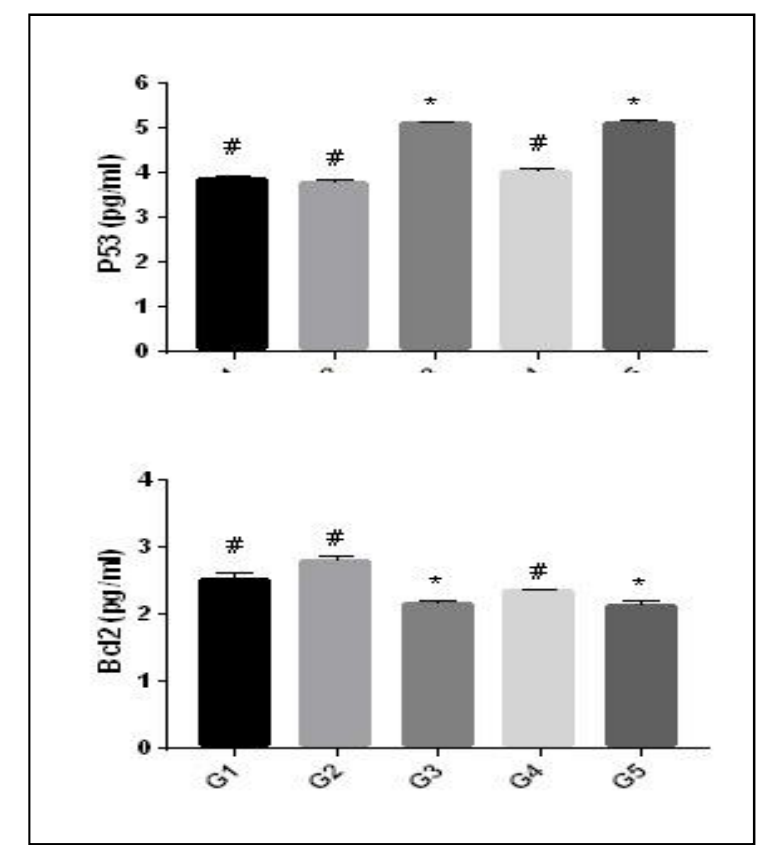

Fig. 3. The changes in P53 and Bcl2 levels in mice liver tissues in all studied groups; data are expressed as mean \pm standard error; G1, control; G2, GSPE; G3, hyperthyroid; G4, posttreated hyperthyroid with GSPE; G5, self-treated hyperthyroid; " significantly different from G3, *significantly different from $\mathrm{G} 1$ 


\subsection{Liver Histopathology}

Liver sections on control and treated mice with GSPE exhibits normal histological structure of hepatocytes (Fig. 4A \& 4B). Liver sections on hyperthyroid mice showed marked vacuolated hepatocytes, marked cellular infiltrations, inflammation, moderate degeneration with necrotic area and mild congestion in central veins and portal vein, surrounded by leucocytic infiltrations (Figs. 4C \& 4D). Liver sections in post treated hyperthyroid mice with GSPE revealed a few vacuolated hepatocytes, moderate cellular infiltrations, and cytoplasmic vacuolations observed when compared to hyperthyroid or selftreated hyperthyroid mice (Fig. 4E). In contrast; self-treated hyperthyroid mice showed marked vacuolated hepatocytes, marked cellular infiltrations and marked degeneration with necrotic area (Fig. 4F).
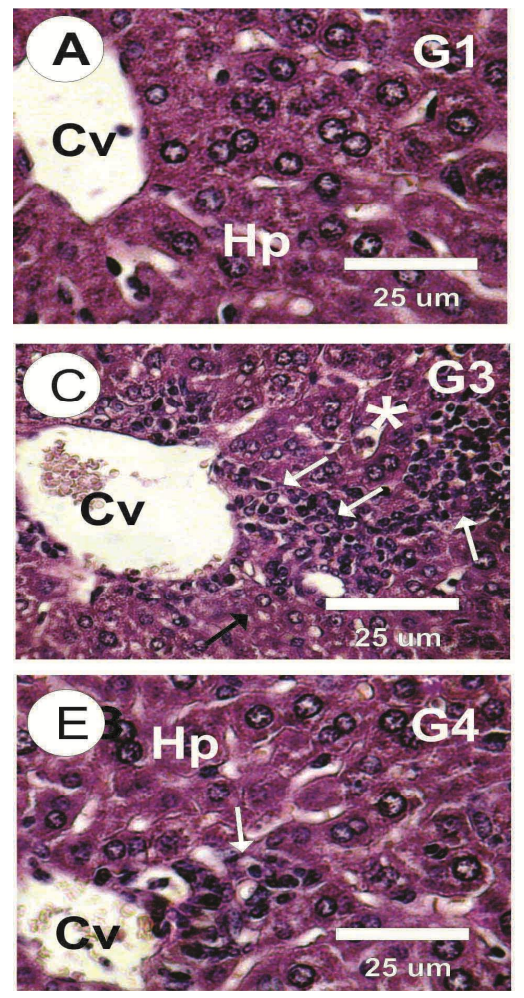

\subsection{Changes in P53 Expression}

Liver sections in control group and GSPE group showed negative expression of P53 (Fig. 5A \& $5 B)$. Strong P53expression were detected in liver sections of hyperthyroid and self-treated hyperthyroid mice (Fig. 5C \& 5D \& 5F). The intensity of P53 expression in hyperthyroid group was increased when compared with control group. Mild positive expressions for P53 were observed in liver sections in post treated hyperthyroid mice with GSPE (Fig. 5E).

\section{DISCUSSION}

The current study has been represented to examine the effect of a hyperthyroidism status on biochemical parameters, oxidative stress parameters, apoptosis, histological and P53 immunohistochemical alterations in liver tissues.
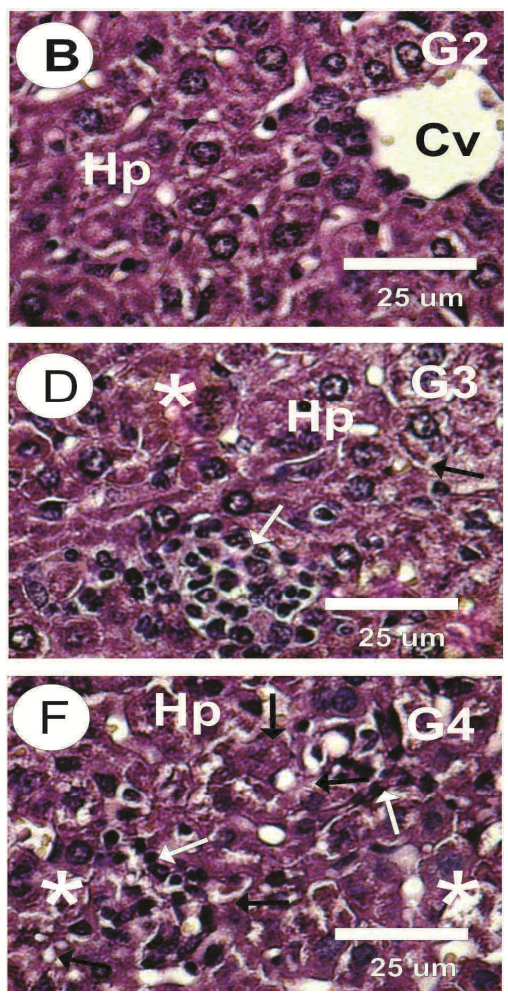

Fig. 4A-4F. Photomicrographs of mice liver sections in the different experimental groups stained with Haematoxylin \& Eosin; A\&B. Normal structure of hepatocytes (Hp) and central vein (cv) in control and GSPE groups revealed C\&D. Marked vacuolated hepatocytes, marked necrosis (star), marked cellular infiltrations (White arrows), and moderate degeneration with necrotic area (Black arrows) in hyperthyroid mice revealed. E. Mild vacuolated hepatocytes (Hp), diffuse Kupffer cells proliferation in between the some hepatocytes and moderate cellular infiltrations (White arrows) in post treated hyperthyroid mice with GSPE. F. Marked vacuolated hepatocytes, marked cellular infiltrations (White arrows) and marked degeneration with necrotic area (star) in self-treated hyperthyroid mice 


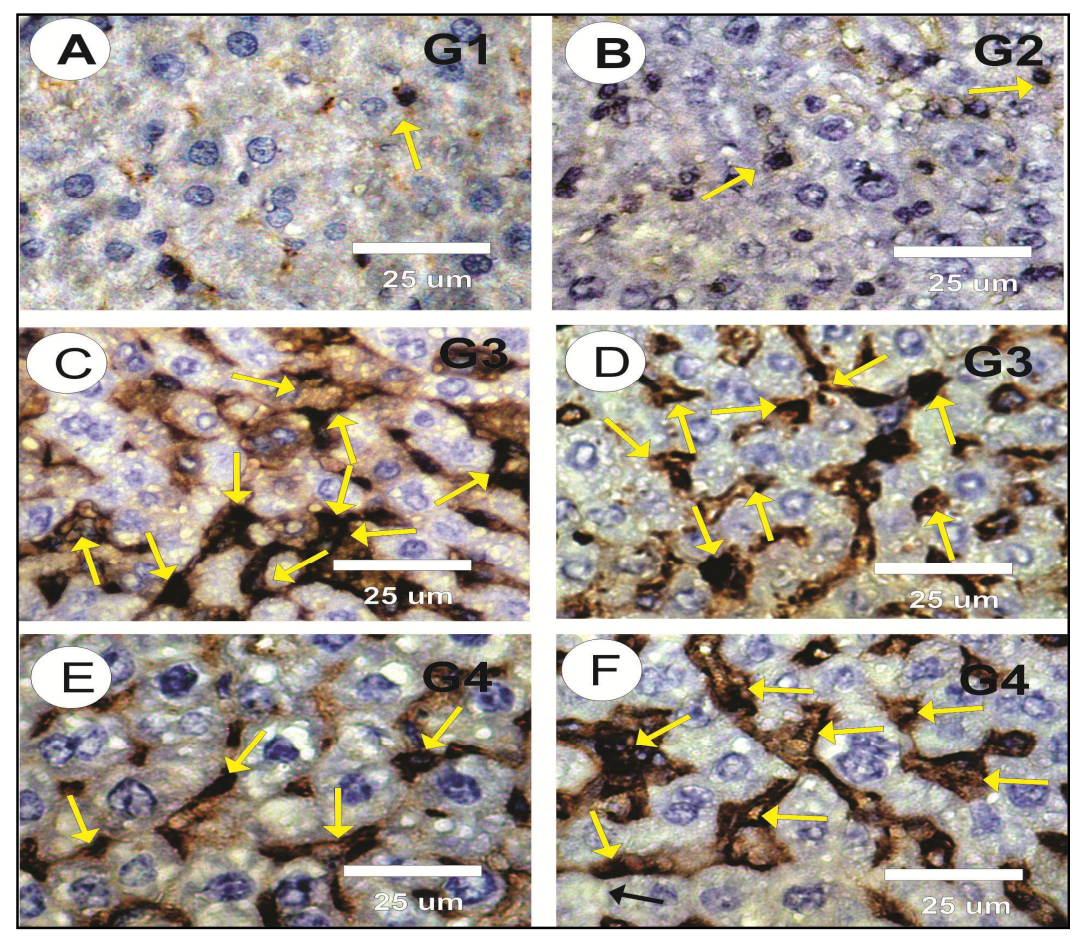

Fig. 5A-5F. Photomicrographs of mice liver sections marked with apoptotic P53 protein; A\&B. Negative or faint positive reactions (arrows) in hepatocyte nuclei in hepatocytes in control and GSPE; C\&D. Strong positive reactions (arrows) in hyperthyroid; E. Moderate to strong positive reactions (arrows) in self-treated hyperthyroid mice. F. Mild positive reactions (arrows) in post treated hyperthyroid mice with GSPE

Our results revealed elevation in serum $T_{3}, T_{4}$ and depression $\mathrm{TSH}$ in mice receiving Eltroxin indicating the hyperthyroid state. This finding is compatible with other studies that used Lthyroxin as an anti-thyroid drug for induction of hyperthyroidism [2-4]. In the current study, depletion in the level of $T_{3}$ and $T_{4}$ and elevation in TSH were detected in post treated hyperthyroid mice with GSPE when compared with hyperthyroid mice. The current outcome agrees with studies of Beltagy et al. [2].

Liver assumes a significant job in thyroid hormones digestion, and correspondingly, thyroid hormones direct hepatic capacity and bilirubin digestion, in this manner as anyone might expect, disorders of either organ can possibly influence capacity of the other [12,13]. In the current results revealed a significance increase in serum ALT, AST, ALP and significance depletion in albumen levels in hyperthyroid mice confirmed that hyperthyroidism induced dysfunction in mice liver. Giannini et al. [38]; Hull et al. [39] who reported that; a significant elevation in serum direct bilirubin, ALT, AST and
ALP in hyperthyroidism. The mechanism of the elevation in serum AST, ALT and ALP activities appears to be relative hypoxia in periventricular regions of the liver [40]. Wang et al. [41] and Upadhyay et al. [42] who reported that; the elevation in the levels of T3 induces hepatocytes apoptosis take place through the mitochondrial dependent pathway activation. In the current results; the treatment of hyperthyroid mice with GSPE modulates liver function parameters as compared with self-treated hyperthyroidism. Current results decide with El-Sayed et al. [43] who indicated the liver protective effects of proanthocyanidin on acetaminophen. Also; Kandemir et al. [44] who studies that; the protective effects of grape seed extract against Cisplatin induced liver toxicity in rabbits.

Changes in thyroid hormone levels are known to tweak elements of numerous tissues by adjusting their cancer prevention agent resistances [45]. Hyperthyroidism is distinguished to improve ROS age and it instigates oxidative worry in liver tissue through upsetting the endogenous star oxidant/against oxidant balance [46]. In the 
present study, treatment of mice with Eltroxin induced hyperthyroidism that induced oxidative stress which play an important role in the damage of DNA [47]. In the current study; elevation in liver MDA and depletion in liver GSH, catalase and SOD levels in hyperthyroid mice. On the other hand, hyperthyroid mice treated with GSPE showed significant depletion in liver MDA and alleviation in GSH, catalase and SOD levels as compared with hyperthyroid and selftreated hyperthyroid mice. Asayama and Kato [48] reported that; the damage in MDA was increase in some organs in rats. Antioxidants contained in the red grape seed extract are able to inactivate superoxide anions and prevent lipid peroxidation [49]. Our results confirm GSPE as a potent antioxidant that can reduce lipid peroxidation in liver tissues. Current results agree with Davies [50] who find that hyperthyroidism tends to increase catalase activity.

Reduced glutathione (GSH) as an oxidative stress marker showed a significant decrease in hyperthyroid rats. This decrease was improved by treatment with GSPE. Administration of GSPE exhibit an increase in antioxidant enzyme activities in hyperthyroid which might be due to its ability to reduce the accumulation of free radical generation. Long et al. [51] reported that; GSPE showed an increase in GSH, catalase and SOD levels that clearly suggest their antioxidant property. GSPE has scavenging character and it can effectively inhibit liver toxicity induced by hyperthyroidism and this is may be attributed to its antioxidant properties.

Apoptosis is an urgent cell action in the conduct of mammalian cells in a wide scope of pathophysiological conditions. Apoptosis of individual cells may introduce a defensive system against neoplastic improvement in the life form by wiping out hereditarily harmed cells [41]. In the present examination; a critical increment in $\mathrm{P} 53$ and lessening in $\mathrm{Bcl} 2$ levels in hyperthyroid mice and the treatment of hyperthyroid mice with GSPE decline in P53 and increment in $\mathrm{Bcl} 2$ levels. Our immunohistochemical results for P53 in liver additionally affirmed these outcomes, in this way, our outcomes uncover the plausibility of the apoptosis event after Eltroxin organization. Our outcomes concur with Kumar et al. [47] who announced that; hyperthyroidism incites apoptosis in rodent liver through enactment of death receptor-interceded pathways. Likewise; Tousson et al. [8,9] accomplishment to discover backwards connection somewhere in the range of P53 and Bcl2. Our outcomes not concur with Diebold et al [53] who neglected to uncover any connection somewhere in the range of' P53 and Bcl2. Our results agree with Eldaim et al. [54] who reported that; GSPE induced inhibition in p53 expression were decrease on kidney in Ehrlich solid tumor.

In the current study; many signs of pathological alterations were observed in liver sections in hyperthyroid mice as marked vacuolated hepatocytes, marked necrosis, marked cellular infiltrations, and moderate degeneration with necrotic area, this outcomes perhaps were a result of oxidative pressure brought about by Eltroxin that expansion digestion and free radicals with the goal that the body's barriers of cell reinforcements can't avoid free radicals that harm liver tissue. Additionally, in our investigation on hyperthyroidism actuated in mice showed that Eltroxin hormone animates the quality answerable for customized passing in liver cells and it was seen in the histological examination a distinction in cell shading and degeneration in the cytoplasm nature just as hyperthyroidism causing ischemia in the liver $[24,47,55]$. In the present investigation GSPE supplementation improvement of liver harm initiated by Eltroxin, this may come back to the job of viability grape seed concentrate mixes against oxidative pressure, irritation and customized cell passing opposition [43].

\section{CONCLUSION}

In conclusion, current work confirmed that; hyperthyroidism induced liver toxicity, oxidative stress, and apoptosis also the treatment with GSPE improved these alterations in liver tissues.

\section{ETHICAL APPROVAL}

The experimental protocol was approved by Local Ethics Committee and Animals Research, King Saud University, Riyadh, Saudi Arabia.

\section{COMPETING INTERESTS}

Author has declared that no competing interests exist.

\section{REFERENCES}

1. Joeimon JL, Mohanraj K, Karthikeyan R, et al. Thyroid dysfunction in patients with liver cirrhosis. Journal of Dental and Medical Sciences 2017; 16(4):18-22.

2. Beltagy D, Mohamed T, El Said A, Tousson E. Beneficial role of ascorbic and 
folic acids antioxidants against thyroxininduced testicular dysfunction in hyperthyroid rats. Environmental Science and Pollution Research. 2016;23(17): 17246-54.

3. Salama A, Tousson E, Ebrahim W, Elwan M. Ameliorating role of folic acid in eltroxine induced hyperthyroid and oxidative stress in rat cortex, hypothalamus and hippocampus. Alexandria Journal of Veterinary Sciences 2017;55(1): 210-216.

4. Tousson E, Ali EM, Ibrahim W, Mansour MA. Proliferating cell nuclear antigen as a molecular biomarker for spermatogenesis in PTU-induced hypothyroidism of rats. Reprod Sci. 2011;18:679-686.

5. Tousson E, Ali EM, Ibrahim W, Mansour MA. Treatment with folic acid ameliorated the histopathological alterations caused by propylthiouracil-induced hypothyroid rat testes. Toxicology and Industrial Health. 2012;28:566-576.

6. Tousson E, Ali EM, Ibrahim W, Ashraf RM. Histopathological and immunohisto chemical alterations in rat heart after thyroidectomy and the role of hemin and ketoconazole in treatment. Biomedicine \& Pharmacotherapy. 2012;66:627-632.

7. Tousson E, Hafez E, Massoud A, Sweef O, Atta N. Protective role of folic acid in thyroxine-induced cardiac hypertrophy in hyperthyroid rat. Biomedicine \& Aging Pathology. 2013;3:89-95.

8. Tousson E, Hafez E, Zaki S, Gad A. P53, $\mathrm{Bcl}-2$ and CD68 expression in response to amethopterin-induced lung injury and ameliorating role of I-carnitine. Biomedicine \& Pharmacotherapy. 2014;8(5):631-639.

9. Tousson E, Hafez E, Zaki S, Gad A. The cardioprotective effects of L-carnitine on rat cardiac injury, apoptosis and oxidative stress caused by amethopterin. Environ Sci Pollut Res. 2016;23:20600-20608.

10. Kim D. et al. Subclinical hypothyroidism and low-normal thyroid function are associated with nonalcoholic steatohepatitis and fibrosis. Clin. Gastroenterol. Hepatol. 2018;16:123-131.

11. Aydemir S, Bayraktaroglu T, Demircan N, Sert M, Açikgoz S, Tekin IO, et al . Effect of hyperthyroidism and propylthiouracil treatment on liver biochemical tests. Int $\mathrm{J}$ Clin Pract. 2005;59(11):1304-1308.

12. Mansourian AR. A review of literatures on the adverse effects of thyroid abnormalities and liver disorders: An overview on liver dysfunction and hyperthyroidism. P J Biological Science. 2013;16: 1641-1652.

13. Bolkiny $\mathrm{Y}$, Tousson E, El-Atrsh A, Akela M, Farg E. Costus root extract alleviates blood biochemical derangements of experimentally induced hypo- and hyperthyroidism in mice. Annual Research \& Review in Biology. 2019;31(5):1-0.

14. Sinha RA, Yen PM. Thyroid hormonemediated autophagy and mitochondrial turnover in NAFLD. Cell Biosci. 2016;6:46.

15. Khemichian S, Ling Fong $T$. Hepatic Dysfunction in Hyperthyroidism. Gastro enterol Hepatol. 2011;7(5):337-339.

16. Bagchi D, Swaroop A, Preuss HG, Bagchi $M$. Free radical scavenging, antioxidant and cancer chemoprevention by grape seed proanthocyanidin: An overview. Mutat Res. 2014;768:69-73.

17. Li SG, Ding YS, Niu Q, Xu SZ, Pang LJ, Ma RL, Jing MX, Feng GL, Liu JM, Guo SX. Grape seed proanthocyanidin extract alleviates arsenic-induced oxidative reproductive toxicity in male mice. Biomed Environ Sci. 2015;28:272-280.

18. Schelz Z, Ocsovszki I, Bózsity N, Hohmann J, Zupko I. Antiproliferative effects of various furanoacridones isolated from Ruta graveolens on human breast cancer cell lines. Anticancer Res. 2016;36: 2751-2758.

19. Sarshar S, Brandt S, Asadi Karam MR, Habibib M, Bouzari S, Lechtenberg M, Dobrindt U, Qin X, Goycoolea FM, Hensel A. Aqueous extract from Orthosiphon stamineus leaves prevents bladder and kidney infection in mice. Phytomedicine 2017;28:1-9

20. Zhou K, Raffoul JJ. Potential anticancer properties of grape antioxidants. J Oncol 2015;80:3294.

21. Al-Rasheed NM, El-Masry TA, Tousson E, Hassan $\mathrm{H}$, Al-Ghadeer A. Protective potential of grape seed proanthocyandins extract against glivec (Imatinib Mesylate) induced liver toxicity and oxidative stress in male rats. Annual Research \& Review in Biology. 2017;20(6):1-9.

22. Zhu FM, Du B, Li J. Effect of ultrafine grinding on physicochemical and antioxidant properties of dietary fiber from wine grape pomace. Food Sci Technol Int. 2014;20:55-62.

23. El-Atrash A, Zaki S, Tousson E, Shoir M. Protective potential of grape seed extract against monosodium glutamate induced liver toxicity and oxidative stress in young 
rats. Journal of Advanced Trends in Basic and Applied Science. 2017;1(3):257-262.

24. Al-Naely A, Shattnan D. Effect of grape seed extract on biochemical factor and histological changes in liver and the kidney in albino rat infected hypo- hyperthyroidism induced laboratory by carbimazole and Ithyroxine. Journal of Global Pharma Technology. 2017;9(9):174-181

25. Thakur C, Saikia TC, Yadav RN. Total serum levels of triiodothyronine (T3) thyroxine (T4) and thyrotropine (TSH) in school going children of Dibrugarh district: an endemic goitre region of Assam. Indian J Physiol Pharmacol. 1997;41(2):167-70.

26. Ibrahim W, Tousson E, Ali EM, Mansour MA. Folic acid alleviates oxidative stress and hyperhomocysteinemia involved in testicular dysfunction of hypothyroid rats. General and comparative endocrinology. 2011 Nov 1;174(2):143-9.

27. Ibrahim W, Tousson E, El-Masry T, Arafa $\mathrm{N}$, Akela M. The effect of folic acid as an antioxidant on the hypothalamic monoamines in experimentally induced hypothyroid rat. Toxicology and industrial health. 2012;28(3):253-61.

28. El-Moghazy M, Zedan NS, El-Atrsh AM, ElGogary M, Tousson E. The possible effect of diets containing fish oil (omega-3) on hematological, biochemical and histopathogical alterations of rabbit liver and kidney. Biomedicine \& Preventive Nutrition. 2014 Jul 1;4(3):371-7.

29. Doumas BT, Watson WA, Biggs HG. Albumin standards and the measurement of serum albumin with bromocresol green. Clin Chim Acta. 1977;31:87-96.

30. Moss DW, Henderson AR. Clinical enzymology CA Burtis, ER Ashwood (Eds.). Tietz Textbook of Clinical Chemistry ( $3^{\text {rd }}$ Ed) 1999. W.B Saunders Company, Philadelphia. 1999;617- 721.

31. Moustafa AH, Ali EM, Moselhey SS, Tousson E, El-Said KS. Effect of coriander on thioacetamide-induced hepatotoxicity in rats. Toxicology and industrial health. 2014;30(7):621-9.

32. Saggu S, Sakeran MI, Zidan N, Tousson $\mathrm{E}$, Mohan A, Rehman H. Ameliorating effect of chicory (Chichorium intybus L.) fruit extract against 4-tert-octylphenol induced liver injury and oxidative stress in male rats. Food and chemical toxicology. 2014;72:138-146.

33. Misra HP, Fridovich I. The role of superoxide anion in the auto-oxidation of epinephrine and a simple assay for super oxidedismutase. Jornal of Biológica Chemsitry. 1972;247: 3170- 3175.

34. Beutler E, Duron O, Kelly BM. Improved method for the determination of blood glutathione. J. Lab. Clin. Med. 1963;61: 882-888.

35. Tousson E, Rafat BM, Hessien M, El Barbary AA, Sami A. P53 and Bcl2 apoptosis proteins in meso-2, 3dimercaptosuccinic acid treated leadintoxicated rabbits. Toxicology and Industrial Health. 2011;27(3):271-8.

36. Tousson E. Histopathological alterations after a growth promoter boldenone injection in rabbits. Toxicology and Industrial Health 2016;32(2):299-305.

37. Abd Eldaim MA, Tousson E, El Sayed IE, Awd WM. Ameliorative effects of Saussurea lappa root aqueous extract against Ethephon-induced reproductive toxicity in male rats. Environmental Toxicology. 2019;34(2):150-9.

38. Giannini EG, Testa $R$ and Savarino V. Liver enzyme alteration: $A$ guide to clinicians. MAJ. 2005;172(3):367-79.

39. Hull K, Horenstein R, Naglieri R, Munir K, Ghany M, Celi FS. Two cases of thyroid storm associated cholestatic jaundice. Endocr Pract. 2007;13:476-480.

40. Biscoveanu M, Hasinski S. Abnormal results of liver function test in patients with Grave's disease. Endocr Pract. 2000;6: 367-369.

41. Wang R, Tan J, Zhang G, Zheng W, Li C. Risk factors of hepatic dysfunction in patients with Graves' hyperthyroidism and the efficacy of 131iodine treatment. Medicine. 2017;96:5(6035).

42. Upadhyay G, Singh R, Kumar A, Kumar S, Kapoor A, God bole MM. Severe hyperthyroidism induces mitochondria mediated apoptosis in rat liver. Hepatology. 2004;39(4):1120-1130.

43. Tousson E, Elgharabawy RM, Elmasry TA. Grape seed proanthocyanidin ameliorates cardiac toxicity induced by boldenone undecylenate through inhibition of nadph oxidase and reduction in the expression of NOX2 and NOX4. Oxidative Medicine and Cellular Longevity. 2018;9434385.

44. Kandemir FM, Benzer F, Ozkaraca $M$, Ceribasi S, Yildirim NC, Ozdemir N. Protective antioxidant effects of grape seed extract in a cisplatin-induced hepatotoxicity model in rabbits. Revue Méd. 2012;163(11):539-545. 
45. Sahoo D, Roy A, Bhanja S, Chainy G. Hypothyroidism impairs antioxidant defence system and testicular physiology during development and maturation. General Comp Endocrinol. 2008;156:63-70.

46. Das K, Chainy GN. Modulation of rat liver mitochondrial antioxidant defence system by thyroid hormone. Biochim Biophys Acta. 2001;1537:1-13.

47. Kumar A, Sinha RA, Tiwari M , Singh R, Koji T, Manhas N, Rastogi L, Pal L, Shrivastava A, Sahu RP, Godbole MM. Hyperthyroidism induces apoptosis in rat liver through activation of death receptormediated pathwaysq. Journal of Hepatology. 2007;46:888-898.

48. Asayama K, Kato K. Oxidative muscular injury and its relevance to hyperthyroidism. Free Radic Biol Med. 1990;8:293-303.

49. Bagchi D, Bagchi M, Stohs SJ, Das DK, Ray SD, Kuszynski CA, Joshi SS, Pruess HG. Free radicals and grape seed proanthocyanidin extract: Importance in human health and disease prevention. Toxicology. 2000;148:187-197.

50. Davies KJ. Oxidative stress, antioxidant defenses and damage removal, repair, and replacement systems. IUBMB Life. 2000; 50:279-289.
51. Chattopadhyay S, Sahoo DK, Subudhi U, Chainy GB. Differential expression profiles of antioxidant enzymes and glutathione redox status in hyperthyroid rats: A temporal analysis. Comp. Biochem. Physiol C Pharmacol Toxicol Endocrinol. 2007;146:383-391.

52. Long $M$, Yang S, Han J, Li P, Zhang $Y$, Dong $S$. The protective effect of grapeseed proanthocyanidin extract on oxidative damage induced by zearalenone in kunming mice liver. Int $\mathrm{J}$ Mol Sci. 2016;17(6):808.

53. Diebold J, Baretton G, Felchner M, Meier W, Dopper K, Schmidt M, Lohrs U. Bcl-2 expression, p53 accumulation, and apoptosis in ovaria carcinomas. Am J Clin Patho.I 1996;105:341-334.

54. Eldaim MA, Tousson E, El Sayed IE, EI AE, Elsharkawy HN. Grape seeds proanthocyanidin extract ameliorates Ehrlich solid tumor induced renal tissue and DNA damage in mice. Biomedicine \& Pharmacotherapy. 2019;115:108908.

55. Tousson E, Hafez E, Massoud A, Sweef $\mathrm{O}$, Atta N. Protective role of folic acid in thyroxine-induced cardiac hypertrophy in hyperthyroid rat. Biomedicine \& Aging Pathology. 2013;3:89-95.

(0) 2019 Aldubayan; This is an Open Access article distributed under the terms of the Creative Commons Attribution License (http://creativecommons.org/licenses/by/4.0), which permits unrestricted use, distribution, and reproduction in any medium, provided the original work is properly cited.

\section{Peer-review history:}

The peer review history for this paper can be accessed here: http://www.sdiarticle4.com/review-history/53015 